\title{
Collection and Evaluation of Coriander Varieties for Growth and Seed Purpose
}

\author{
Ravi Pujari $^{1^{*}}$, A. R. Kurubar ${ }^{2}$, T. Chethan ${ }^{3}$ and Satish Kale ${ }^{3}$ \\ ${ }^{1}$ College of Agriculture, Bheemarayanagudi, India \\ ${ }^{2}$ College of Agriculture, Raichur, India \\ ${ }^{3} \mathrm{KVK}$, Raddewadagi, India \\ *Corresponding author
}

A B S T R A C T

\section{Keywords \\ Coriander, \\ Evaluation, \\ DWDC-1, Seed \\ Yield, Varieties \\ Article Info \\ Accepted: \\ 20 June 2020 \\ Available Online: \\ 10 July 2020}

\begin{abstract}
The present investigation entitled "Collection and evaluation of coriander genotypes for seed purpose" was carried out during rabi season of the year 2018 \& 2019 at the College of Agriculture, Bheemarayanagudi. The study consisted of sixteen coriander varieties using randomized block design and each treatment was replicated thrice. The varieties viz., Suguna, Sindhu, Supha, AD-1, Sadana, Swathi, Susthira, GDLC 1, DWDC-1, Sudha, Co 1, Co 2, Gcr-1, Gcr-2, Rcr436, Chamnal Local were studied under investigation. The pooled results revealed that variety DWDC-1 was found significantly superior in seed yield (13.76 q/ha) and required least number of days for maturity (92.17 days). The yield contributing parameters seed yield per plant $(6.41 \mathrm{~g})$, Seed yield per plot $(564.37 \mathrm{~g})$ and 1000 seed weight $(10.27 \mathrm{~g})$ were observed significantly highest in DWDC-1. Hence, this variety can be included in further breeding programme for improving the seed yield.
\end{abstract}

\section{Introduction}

Coriander (Coriandrum sativum L.) is an important seed spice crop belongs to family Apiaceae (Umbelliferae) with a chromosome number of $2 n=22$. Mediterranean region is the centre of origin of this crop. Coriander is an annual herbaceous cross pollinated crop. Its name has been derived from Greek word "Koris" means bed-bug, because of unpleasant, fetid bug like odour of the green unripened fruits. Coriander ranks first among the seed spices with respect to export. It is the major ingredient of curry powder up to $40 \%$ by weight and also forms an important ingredient for several alcoholic beverages, particularly gin.

Seeds are also used as tonic, carminative, diuretic, stomachic and as an aphrodisiac. Oleoresin from coriander is used as a flavouring agent and as an ingredient in pharmaceutical formulation and in perfumery (Singh et al., 2006). Coriander fruits are an important spice of many countries of Europe, Northern Africa, West, Central and South Asia. In the Mediterranean region, coriander cultivation dates back to ancient Egypt; in Europe, coriander is known since the middle ages (Anonymous, 2012). 


\section{Materials and Methods}

The experimental material for the present study comprised of 16 coriander varieties obtained from different institutions and these were tested for growth and yield attributes during November, 2018 to February, 2019 \& November, 2019 to February, 2020 at Horticulture Department, College of Agriculture Bheemarayanagudi, which is North-Eastern dry zone of Karnataka (Region II, Zone 2) located between $16043 \mathrm{~N}$ and 760 51 E longitude at an elevation of 411.75 meters above MSL characterized by dry climate with an average annual rainfall of $774.1 \mathrm{~mm}$.

The experiment was laid out by adopting Randomized Complete Block Design (RBD) with three replications and the treatments in each replication were allotted randomly. Farm Yard Manure at the rate of 20 tons per hectare along with full dose of phosphorus and potassium and half dose of nitrogen (60:40:20 $\mathrm{kg}$ NPK/ha) was applied and beds (2 m X 1.5 $\mathrm{m})$ were leveled and shallow furrows were made.

The crop was sown at November, 2nd 2019 at a spacing of $20 \times 15 \mathrm{~cm}$ (shallow depth of 1$1.5 \mathrm{~cm}$ ) and seeds germinated in 7-10 days. Thinning was done at 30 days after sowing to maintain a spacing of $10 \mathrm{~cm}$ with in a row. Five randomly selected plants in each treatment in each replication were tagged for recording observations on plant characters and the mean values were subjected to statistical analysis to get the pooled data for two year study.

The following observations were recorded on plant height $(\mathrm{cm})$, number of primary and secondary branches per plant, days to fifty per cent flowering, number of umbels per plant, number of umbellets per umbel, number of seeds per umbellet, days to maturity and seed yield $\mathrm{kg}$ per plot and seed yield per hectare. The list of varieties is presented in Table 1.

\section{Results and Discussion}

\section{Growth attributes}

The pooled entries under evaluation varied significantly with respect to growth and yield traits are presented in Table 2. At 30th DAS, variety Sadhana recorded maximum plant height $(10.77 \mathrm{~cm})$, followed by Swathi $(10.42$ $\mathrm{cm})$ At 60th DAS the variety Sindhu recorded maximum plant height $(46.37 \mathrm{~cm})$, and followed by Suguna $(46.09 \mathrm{~cm})$. At 90th DAS, the variety Gcr-2 recorded maximum plant height $(54.45 \mathrm{~cm})$, which was statistically at par with the variety Gcr-1 $(52.43 \mathrm{~cm})$.

These differences in plant height among the varieties might be due to the genetic makeup of the plant and its expression to the growing soil and environmental conditions. The variation in plant growth of different coriander varieties were also observed by Kalidasu et al., (2008), Verma et al., (2014) in coriander, Meena et al., (2014) coriander, which confirms the results of present investigation.

The maximum (9.20) number of primary branches was recorded in variety Sudha, which was statistically at par with the variety Sindhu (8.96). There variety DWDC-1 recorded significantly highest (24.70) number of secondary branches.

The significant difference in early stages of growth was observed, as during germination and growth initiation process, the varieties might not have expressed their genetic potential. The findings of Agasimani (2014) in coriander, Verma et al., (2014) in coriander, Meena et al., (2014) in coriander, supports the results of present findings. 
Table.1 List of coriander varieties evaluated in the study

\begin{tabular}{|l|l|}
\hline Sl.No & Variety \\
\hline $\mathbf{1}$ & Suguna \\
\hline $\mathbf{2}$ & Sindhu \\
\hline $\mathbf{3}$ & Supha \\
\hline $\mathbf{4}$ & AD-1 \\
\hline $\mathbf{5}$ & Sadana \\
\hline $\mathbf{6}$ & Swathi \\
\hline $\mathbf{7}$ & Susthira \\
\hline $\mathbf{8}$ & GDLC 1 \\
\hline $\mathbf{9}$ & DWD \\
\hline $\mathbf{1 0}$ & Sudha \\
\hline $\mathbf{1 1}$ & Co 1 \\
\hline $\mathbf{1 2}$ & Co 2 \\
\hline $\mathbf{1 3}$ & Gcr-1 \\
\hline $\mathbf{1 4}$ & Gcr-2 \\
\hline $\mathbf{1 5}$ & Rcr436 \\
\hline $\mathbf{1 6}$ & Local \\
\hline
\end{tabular}

Table.2 Performance of different coriander varieties in respect of growth attributes

\begin{tabular}{|c|c|c|c|c|c|c|}
\hline \multirow[b]{2}{*}{ SI No. } & \multicolumn{4}{|c|}{ Plant Height (cm) } & \multirow{2}{*}{$\begin{array}{c}\text { Primary } \\
\text { branches at } \\
\text { harvest }\end{array}$} & \multirow{2}{*}{$\begin{array}{c}\text { Secondary } \\
\text { branches per } \\
\text { plant at } \\
\text { harvest }\end{array}$} \\
\hline & Treatments & 30 DAS & 60 DAS & 90 DAS & & \\
\hline 1. & Suguna & 10.30 & 46.09 & 48.73 & 8.20 & 19.22 \\
\hline 2. & Sindhu & 10.26 & 46.37 & 51.07 & 8.96 & 21.73 \\
\hline 3. & Supha & 9.36 & 44.70 & 48.61 & 8.33 & 18.62 \\
\hline 4. & AD-1 & 8.29 & 42.73 & 47.95 & 6.67 & 15.94 \\
\hline 5. & Sadana & 10.77 & 45.83 & 48.90 & 8.34 & 18.54 \\
\hline 6. & Swathi & 10.42 & 42.88 & 50.14 & 7.80 & 21.32 \\
\hline 7. & Susthira & 9.13 & 43.07 & 47.05 & 6.62 & 19.31 \\
\hline 8. & GDLC- 1 & 9.68 & 45.21 & 48.68 & 7.88 & 16.61 \\
\hline 9. & DWDC-1 & 9.87 & 44.85 & 48.95 & 8.18 & 24.70 \\
\hline 10. & Sudha & 10.41 & 45.46 & 51.29 & 9.20 & 18.76 \\
\hline 11. & Co 1 & 8.42 & 43.42 & 46.69 & 7.87 & 19.29 \\
\hline 12. & Co 2 & 8.03 & 45.06 & 48.87 & 6.64 & 14.61 \\
\hline 13. & Gcr-1 & 8.73 & 44.90 & 52.43 & 8.15 & 17.51 \\
\hline 14. & Gcr-2 & 8.00 & 49.80 & 54.45 & 6.54 & 17.24 \\
\hline 15. & Rcr436 & 7.97 & 47.03 & 52.29 & 8.45 & 19.21 \\
\hline \multirow[t]{3}{*}{16.} & Local & 8.02 & 46.85 & 50.22 & 8.79 & 17.26 \\
\hline & Sem \pm & 0.246 & 0.814 & 0.848 & 0.260 & 0.720 \\
\hline & $\mathrm{CD}(5 \%)$ & 0.713 & 2.353 & 2.451 & 0.752 & 2.082 \\
\hline
\end{tabular}


Table.3 Performance of different coriander varieties in flowering attributes

\begin{tabular}{|l|l|c|c|c|c|c|c|}
\hline SI.No & Treatments & $\begin{array}{c}\text { No of days taken } \\
\text { for flower } \\
\text { initiation }\end{array}$ & $\begin{array}{c}\text { Days to } \\
\mathbf{5 0 \%} \text { flower } \\
\text { initiation }\end{array}$ & $\begin{array}{c}\text { Number of } \\
\text { umbels per } \\
\text { plant }\end{array}$ & $\begin{array}{c}\text { Number of } \\
\text { umbellets } \\
\text { per umbel }\end{array}$ & $\begin{array}{c}\text { Number of } \\
\text { seeds per } \\
\text { umbel }\end{array}$ & $\begin{array}{c}\text { Days to } \\
\text { maturity }\end{array}$ \\
\hline $\mathbf{1 .}$ & Suguna & 41.77 & 52.54 & 45.71 & 3.95 & 29.89 & 94.00 \\
\hline $\mathbf{2 .}$ & Sindhu & 42.16 & 52.67 & 45.23 & 3.61 & 37.95 & 100.67 \\
\hline $\mathbf{3 .}$ & Supha & 41.54 & 55.51 & 44.65 & 3.40 & 35.78 & 104.17 \\
\hline $\mathbf{4 .}$ & AD-1 & 40.94 & 49.57 & 39.43 & 3.15 & 33.19 & 94.50 \\
\hline $\mathbf{5 .}$ & Sadana & 49.52 & 58.43 & 42.21 & 2.15 & 34.13 & 104.67 \\
\hline $\mathbf{6 .}$ & Swathi & 40.21 & 51.63 & 50.54 & 4.31 & 38.38 & 96.33 \\
\hline $\mathbf{7 .}$ & Susthira & 40.06 & 50.91 & 45.38 & 2.66 & 35.69 & 95.67 \\
\hline $\mathbf{8 .}$ & GDLC -1 & 39.92 & 52.88 & 41.86 & 3.58 & 34.80 & 93.83 \\
\hline $\mathbf{9 .}$ & DWDC-1 & 39.12 & 48.07 & 46.87 & 7.34 & 37.89 & 92.17 \\
\hline $\mathbf{1 0 .}$ & Sudha & 46.45 & 56.81 & 53.37 & 4.78 & 38.31 & 103.00 \\
\hline $\mathbf{1 1 .}$ & Co 1 & 48.65 & 60.07 & 44.95 & 4.50 & 35.04 & 106.33 \\
\hline $\mathbf{1 2 .}$ & Co 2 & 50.49 & 60.03 & 45.02 & 3.48 & 35.33 & 109.00 \\
\hline $\mathbf{1 3 .}$ & Gcr-1 & 49.89 & 59.91 & 35.36 & 4.38 & 28.34 & 105.83 \\
\hline $\mathbf{1 4 .}$ & Gcr-2 & 49.95 & 59.96 & 34.77 & 4.98 & 29.67 & 109.50 \\
\hline $\mathbf{1 5 .}$ & Rcr436 & 48.08 & 59.64 & 46.94 & 4.37 & 34.11 & 108.17 \\
\hline $\mathbf{1 6 .}$ & Local & 50.25 & 59.00 & 46.29 & 4.32 & 34.88 & 106.17 \\
\hline & Sem \pm & 0.618 & 0.622 & 1.150 & 0.133 & 1.091 & 0.409 \\
\hline & CD $(5 \%)$ & 1.786 & 1.912 & 3.322 & 0.384 & 3.153 & 1.183 \\
\hline
\end{tabular}

Table.4 Performance of different coriander varieties in seed yield attributes

\begin{tabular}{|l|l|c|c|c|c|}
\hline SI.No & Treatments & $\begin{array}{c}\text { Seed yield per } \\
\text { plant (g) }\end{array}$ & $\begin{array}{c}\text { Seed yield per } \\
\text { plot } \mathbf{( g )}\end{array}$ & Seed yield (q/ha) & $\begin{array}{c}\text { Test weight (g) } \\
\text { 1000 seed }\end{array}$ \\
\hline $\mathbf{1 .}$ & Suguna & 4.11 & 361.53 & 9.03 & 8.05 \\
\hline $\mathbf{2 .}$ & Sindhu & 3.57 & 314.16 & 7.56 & 9.06 \\
\hline $\mathbf{3 .}$ & Supha & 4.22 & 366.58 & 8.88 & 6.44 \\
\hline $\mathbf{4 .}$ & AD-1 & 3.37 & 296.85 & 7.28 & 8.22 \\
\hline $\mathbf{5 .}$ & Sadana & 4.81 & 423.28 & 10.53 & 6.38 \\
\hline $\mathbf{6 .}$ & Swathi & 2.25 & 198.15 & 4.94 & 4.28 \\
\hline $\mathbf{7 .}$ & Susthira & 4.51 & 396.73 & 9.82 & 6.57 \\
\hline $\mathbf{8 .}$ & GDLC- 1 & 4.46 & 392.19 & 9.76 & 5.43 \\
\hline $\mathbf{9 .}$ & DWDC-1 & 6.41 & 564.37 & 13.76 & 10.27 \\
\hline $\mathbf{1 0 .}$ & Sudha & 5.51 & 486.59 & 11.99 & 8.77 \\
\hline $\mathbf{1 1 .}$ & Co 1 & 4.48 & 388.77 & 9.49 & 5.67 \\
\hline $\mathbf{1 2 .}$ & Co 2 & 4.36 & 377.10 & 9.37 & 6.24 \\
\hline $\mathbf{1 3 .}$ & Gcr-1 & 3.93 & 335.55 & 8.39 & 5.71 \\
\hline $\mathbf{1 4 .}$ & Gcr-2 & 4.08 & 358.60 & 8.97 & 6.35 \\
\hline $\mathbf{1 5 .}$ & Rcr436 & 3.29 & 289.52 & 7.24 & 5.38 \\
\hline $\mathbf{1 6 .}$ & Local & 3.83 & 336.89 & 8.89 & 6.47 \\
\hline & SEm \pm & 0.136 & 11.487 & 0.306 & 0.117 \\
\hline & CD $(5 \%)$ & 0.394 & 33.177 & 0.884 & 0.339 \\
\hline
\end{tabular}




\section{Flowering attributes}

The pooled data in respect of flowering attributes are presented in Table 3. Number of days required to flower initiation was least (39.12) in the variety DWDC-1 which was statistically at par with the variety GDLC-1 (39.92).

Number of days taken for 50 percent flowering was least least (48.07) in the variety DWDC-1 which was statistically at par with the variety AD-1 (49.57). Number of umbels per plant was recorded and the highest (53.37) was recorded in variety Sudha which was statistically at par with the variety Swathi (50.54). Number of umbellets per umbel was significantly highest (7.34) in the variety DWDC-1. Number of seeds per umbel was recorded highest in Swathi (38.38) which was statistically at par with the variety Sudha (38.31). Least number of DAYS to maturity was recorded in DWDC-1 (92.17).

The similar variations among different coriander varieties have reported by Kalidasu et al., (2008) in sadhana varieties of coriander, Moniruzzaman et al., (2013) in coriander and Velayudham et al., (2006) supports the results of present findings.

\section{Seed yield attributes}

The pooled data in respect of days to seed harvesting in coriander were significantly influenced by different varieties and are presented in Table 4. Seed yield per plant $(6.41 \mathrm{~g})$, seed yield per plot $(564.37 \mathrm{~g})$, seed yield per hectare $(13.76 \mathrm{q} / \mathrm{ha})$ and the test weight (10.27 g) was found to be significantly highest in DWDC-1 which was followed by the variety Sudha.

The yield is the result of interaction of the variety to a given agro climatic and management factors. The variations in yield among the coriander varieties were also reported by several workers Malik and Tehlan (2013) in coriander, Garid et al., (2015) in coriander and Meena et al., (2014) in coriander.

In conclusion the evaluation of present study concludes that, the significant variations were observed in growth and yield parameters of different varieties of coriander. The variety DWDC-1 showed significantly superior performance in respect of seed yield. Thus, it was concluded that, DWDC-1 is well suited for UKP command area of North-Eastern dry zone of Karnataka (Region II, Zone 2).

\section{References}

Agasimani, A. Evaluation of coriander (Coriandrum sativum L.) genotypes for fresh and dry biomass yield under hill zone of Karnataka. Int. J Agric. Sci. 2014: 10(2): 747-750.

Anonymous (2012). Cultivation of coriander for spice and quality seed. Spice India, 25(4): 7-15.

Garid, A, Birla D, Tambi KN. Evaluation of coriander varieties for growth, economics and yield. Ann. of Pl. Soil Res. 2015: 17(2): 224-226.

Kalidasu G, Sarada C and Reddy T Y (2008). Eficacy of biofertilizers on the performance of rainfed coriander (Coriandrum sativum L.) in vertisols. $J$ Spices and Aromatic Crops 17(2): 98102.

Malik, T. P. and Tehlan S. K, 2013, Performance of coriander (Coriandrum sativum L.) varieties for growth and seed yield. Int. J. Seed Spices, 3(2): 8990.

Meena K Y, Kale S V and Meena P O (2014). Correlation coefficient and path analysis in coriander. International Journal of Scientific and Research Publications, 4(6): 2250-3153. 
Meena M L, Kumar V, Kumar S, Yadav Y C and Kumar A (2010). Genetic variability, heritability, genetic advance, correlation coeficient and path analysis in coriander. Indian $J$ Hort 67: 242-246.

Moniruzzaman, M., Rahman, M. M., Hossain, M. M., Sirajul Karim, A. J. M. and Khalig, Q. A., 2013, Evaluation of coriander (Coriandrum sativum L.) genotypes for seed yield and yield contributing characters. Bangladesh J. Agril. Res., 38(2): 189-202.

Singh G, Maurya S, De lampasona MP Catalan CAN. Studies on essential oils, part 41. Chemical composition, antifungal, antioxidant and sprout suppressant activities of coriander
(Coriandrum sativum L.) essential oil and its oleoresin. Flavour and Fragrance J. 2006: 21(3): 472-479.

Velayudham A, Hanamashetti SI, Madalageri MB, Wali MC. Evaluation of coriander genotypes during 2003- 2004 kharif and rabi seasons. Proc. Natl. Sem. Emerging Trends in Production, Quality, Processing \& Export of Spice. Coimbatore, 2006; 11:28-29.

Verma P, Doshi V and Solanki R K (2014). Genetic variability assessed in Coriander (Coriandrum sativum L.) over years under environmental conditions of South Eastern Rajasthan (Hadoti Region) Int J Seed Spices 4(2): 94-95.

\section{How to cite this article:}

Ravi Pujari, A. R. Kurubar, T. Chethan and Satish Kale. 2020. Collection and Evaluation of Coriander Varieties for Growth and Seed Purpose. Int.J.Curr.Microbiol.App.Sci. 9(07): 24672472. doi: https://doi.org/10.20546/ijcmas.2020.907.289 